\title{
Könnyen érthető hírek és azok készítése
}

\begin{abstract}
A tanulmányban - szemle jelleggel - nemzetközi színtérröl gyűjtött példákat mutatunk be a könnyen érthető hírkészítésre, illetve ehhez kapcsolódóan ismertetem saját innovációs tevékenységemet, melyet a Vajdaságban valósítottam meg.

A könnyen érthető kommunikáció fogalma és gyakorlata már több évtizede jelen van a nemzetközi színtéren. A tömegtájékoztatáshoz füződő jog áttekintését követően a könnyen érthető hírkészítés lépéseit ismertetem. Bemutatok amerikai, német, svéd, belga és magyar jó gyakorlatokat. Szerbia még nem tartozik az Európai Unióhoz, de egy kezdeményezésnek köszönhetően már a vajdasági magyar területeken is ismerik a könnyen érthető kommunikációt, és az emberek könnyen érthető híreket olvashatnak nap mint nap a világhálón. Bízom abban, hogy a vajdasági innováció mintául szolgálhat olyan hírportálok főszerkesztőinek és újságíróinak, akik fontosnak tartják, hogy a hírek minden emberhez eljuthassanak.

Kulcsszavak: értelmi akadályozottság, könnyen érthető kommunikáció, tömegtájékoztatáshoz füződő jog, könynyen érthető hírek, külföldi jó gyakorlatok, magyarországi és vajdasági innovációk
\end{abstract}

\section{BeVEzető}

A könnyen érthetö kommunikációról először 2018-ban hallottam, amikor Szabadkán részt vettem az „Inkluzív fejlesztő szakpedagógia” szakirányú továbbképzésben. Ezt a továbbképzést a Szegedi Tudományegyetem Juhász Gyula Pedagógusképző Kar Gyógypedagógus-képző Intézete indította. Már a képzés alatt megfogott az, hogy mennyire fontos célja van a könnyen érthető kommunikációnak (KÉK). Tudtam, hogy többé nem engedhetem el ezt a gondolatot. Hazámban, a Vajdaságban is szeretném tovább vinni a hírét, és szeretném megismertetni az emberekkel. Elhatároztam, hogy elöször körülnézek a nagyvilágban: utánanézek annak, hogy külföldön hogyan, milyen formában, milyen mennyiségben jelenítenek meg könnyen érthetö tartalmakat. Vajon milyen innovációk léteznek? Van-e olyan innováció, amit én is meg tudnék valósítani a környezetemben?

Nagyszerủ külföldi mintákat találtam. Külföldön szinte mindenféle tartalom megtalálható könnyen érthető formában. Németországban, Svédországban vagy Amerikában sok jó példát találtam arra, hogy az információhoz való jogot hogyan lehet például a hírekhez való hozzáférés területén biztosítani.

A sok vonzó példával való megismerkedés után megfogalmazódott bennem, hogy Szabadkán is szükség lenne egy könnyen érthető hírportál bevezetésére. Ez a szabadkai székhelyű, magyar nyelvü Pannon RTV-ben tűnt megvalósíthatónak.

A szerkesztőség engedélyezte, hogy az általuk megírt aktuális híreket átírjam könnyen érthető hírekké. Ezeket a híreket meg is osztották a hivatalos weboldalukon. Így valóban mindenkihez eljuthattak a vajdasági KÉK-hírek. Nagy öröm, hogy a kezdeményezés tartós projektté vált. Idén januárban a Pannon RTV weboldalán a KÉK-hírek 2 éves lett.

Tanulmányomban a külföldi jó gyakorlatokat és saját innovációmat fogom bemutatni. Azt remélem, hogy még több emberben tudatosul: a könnyen érthető üzenetek készítése hittel teli, komoly elhivatottság és feladat. 


\section{AZ INFORMÁCIÓHOZ, AZON BELÜL A TÖMEGTÁJÉKOZTATÁSHOZ FÚZŐDŐ JOG}

A Fogyatékossággal élő személyek jogairól szóló ENSZ egyezmény a 9. cikkében a hozzáférhetőséget fogalmazta meg célul. Felszólítja az államokat, hogy tegyék könnyen elérhetővé az információs szolgáltatásokat, dokumentációkat, médiát (tv, rádió, újságok) a fogyatékos emberek számára. A tömegtájékoztatás szereplőinek alkalmazkodniuk kellene az emberek valós szövegértelmezési képességeihez (Csató, 2002). Ez az alapja a teljes körű részvételnek, aktív állampolgári létnek. Így lehetne elhárítani azokat az akadályokat, amelyek eddig megnehezítették az információkhoz való hozzáférést (Farkasné \& Graf-Jaksa, 2009).

A fogyatékosságügyi ENSZ egyezmény 9. cikk d. pontja felhívja a figyelmet arra, hogy mennyire fontos, hogy a fogyatékos emberek, ezen belül az értelmi sérült személyek az interneten is tudjanak informálódni. Ők is tájékozódni szeretnének a nagyvilág híreiről, mint minden más ember. A 21. század embere általában az online felületeken tájékozódik leginkább és leggyakrabban. Fontos a fogyatékosságügyi ENSZ egyezmény hivatkozott cikke, mert külön megszólítja a tömegtájékoztatást nyújtó szolgáltatókat, hogy tegyenek meg mindent annak érdekében, hogy a tömegtájékoztatás akadálymentes legyen az internetes felületeken is.

\section{A KÖNNYEN ÉRTHETŐ HÍREK KÉSZÍTÉSÉNEK LÉPÉSEI}

Léteznek általános útmutatók arról, hogyan kell könnyen érthető kiadványt készíteni. Így például megtudhatjuk, hogyan kell a könnyen érthető kiadvány célját és tartalmát meghatározni. Fontos elv a könnyen érthető üzenet könnyen érthetőségének ellenőriztetése is. Ezeknek az útmutatóknak az ismerete nagy segítséget jelent azok számára, akik először próbálkoznak könnyen érthető kiadványt írni. A szempontok mindenképpen hasznosak, de nem szabad azonban elfelejteni azt sem, hogy a könynyen érthető üzenet készítése egy alkotó folyamat, amelynek során a szabályokat nem kell feltétlenül mereven betartani. A szerkesztők, illusztrátorok, fotósok, és más közremüködők kiteljesíthetik tehetségüket, hozzájárulva ezzel a valóban könnyen érthető információk terjesztéséhez (Csató, 2002).

A könnyen érthető üzenet készítésének általam alkalmazott lépéseit az alábbiakban mutatom be.

\section{A könnyen érthetö hír célja és célcsoportja}

A könnyen érthető információ készítésének elsődleges célja az információ akadálymentesítése.

A könnyen érthető hír céljának meghatározását mérlegelni kell: vajon milyen tartalmú hír érdekelheti a célcsoport tagjait? Ha az olvasó élvezi a könnyen érthető hír olvasását, akkor mondhatjuk azt, hogy a cél megvalósult (Farkasné \& Graf-Jaksa, 2009). 
Fontos tehát azt meghatározni, hogy kinek készül a könnyen érthető hír. A könynyen érthető kommunikáció elsődleges célcsoportját az értelmi sérült emberek alkotják. A másodlagos célcsoport pedig az üzenet megértéséhez más okok miatt támogatást igénylő személyek képezik (Farkasné, 2017).

Fontos, hogy legyen olyan értelmi sérült munkatársunk, aki tapasztalatával segíteni fog akár a témák kiválasztásában, érdekes javaslatok és ötletek felvetésében, valamint a könnyen érthető hír könnyen érthetőségének az ellenőrzésében (Farkasné \& Graf-Jaksa, 2009). Ezt a személyt tapasztalati szakértőnek is nevezhetjük. A könnyen érthető hírek könnyen érthetőségének ellenőrzésével aktív munkát végezhet, a könnyen érthető kommunikáció szakemberévé válhat (Inclusion Europe \& ÉFOÉSZ, 2009).

\section{Az üzenet típusa és tartalma}

Mint minden embernek, úgy az értelmi sérült személyeknek is fontos az, hogy olyan információkhoz jussanak hozzá, amelyek az életük szempontjából fontosak, és amelyek könnyebbé tehetik a mindennapjaikat. Például tájékoztatás a helyi tömegközlekedésről, az orvosnál várható szituációkról, a pénz használatáról vagy a háztartási eszközök alkalmazásáról, a helyi és az országos választásokon való részvételről, a kötelezettségekről és a jogokról (Csató, 2002).

Fontos támogatni a célcsoport általános ismeretszerzését például könnyen érthető hírekkel vagy arról, hogy ott, ahol élnek (ország, város, falu), kitöl és miben kérhetnek segítséget. Például hogyan vehetnek igénybe különböző támogatásokat (családi pótlék, szociális támogatás nagycsaládosoknak, munkanélkülieknek stb.).

A könnyen érthető hírek lehetnek például az aktuális hírek, politikai hírek, gazdasági hírek, jogi hírek, kulturális, vallási, rekreációs programokról szóló hírek, egészségügyi hírek, fogyasztói, vásárlói hírek vagy általános közlekedési hírek.

A könnyen érthető üzenet lehet elsődleges vagy másodlagos szöveg. Az elsődleges könnyen érthető szöveg eredeti, korábban még nem megírt szövegeket jelent. A másodlagos szöveg egy már létező szöveg könnyen érthető nyelvi szintre történő fordítását jelenti (Farkasné, 2017).

A szöveg lehet akár elsődleges, akár másodlagos, a legfontosabb mindig a következetesen, logikusan megírt, egymásra épülö tartalom. A tartalom összeállítását megkönnyítheti az, ha vázlatot készítünk arról, hogy mit szeretnénk szövegbe foglalni.

A tartalom meghatározásánál is egyeztessünk a tapasztalati szakértővel. Ötleteit, észrevételeit, kérdéseit jegyezzük le (Csató, 2002).

\section{A könnyen érthető hír megírásának legfontosabb szempontja}

Használjuk a magyar nyelven elérhető általános útmutatókat.

Talán a legfontosabb, hogy olyan kifejezéseket használjunk, amely a célközönség számára érthető, szókincsüknek valószínűsíthetően része. A cél az, hogy a szöveget minél több ember meg tudja érteni, és hasznát vegye a mindennapi életben. 


\section{A könnyen érthető üzenet érthetőségének ellenőrzése az értelmi sérült személy segítségével}

Amikor készen vagyunk a könnyen érthető hírrel, akkor a tapasztalati szakértő olvassa el és értelmezze azt. A számára nem, vagy nehezen érthetö részeket vele közösen javítsuk. Az elkészült könnyen érthetö hír csak akkor kerülhet a nyilvánosság elé, ha annak érthetőségét a tapasztalati szakértő ellenőrizte. Ne siettessük a munkájában! Érezze azt, hogy van ideje nyugodtan áttanulmányozni, megérteni a szöveg tartalmát. A képek, illusztrációk, szimbólumok esetében is fontos a javítás akkor, ha az ellenőrzést végző személy számára nem világos, vagy nem érthető azok jelentése. $\mathrm{Ha}$ a javaslatok alapján javítottuk a híreket, akkor újra ellenőriztessük a szöveget (Csató, 2002).

A legfontosabb, hogy valóban adjunk a tapasztalati szakértő véleményére. Amit csak lehet, azt úgy javítsunk ki a szövegben, ahogyan azt javasolta. Lehetnek azonban olyan esetek, amikor nem értünk egyet a javaslattal. Például egy intézmény vagy szervezet nevét nem tudjuk leegyszerüsíteni még akkor sem, ha az értelmetlen a tapasztalati szakértő számára. Ilyen esetben meg kell értetnünk a tapasztalati szakértőkkel, hogy ezen nem lehet változtatni, mert ez egy állandó megnevezés. Egy adott intézményt annak a valós elnevezésével kell használnunk, ezt a formát kell alkalmaznunk a könnyen érthető szövegben is (Inclusion Europe \& ÉFOÉSZ, 2009).

Az első ellenőrzést és javítást követően ismét konzultálnunk kell a tapasztalati szakértőnkkel. Újra és újra meg kell kérni őt arra, hogy ellenőrizze a folyamatosan javított kiadványt. Az ellenőrzés és a javítás folyamatának egyfajta körforgásban kell megvalósulnia a könnyen érthető kiadvány szerkesztői és a tapasztalati szakértők között. Amikor minden felvetésre választ adtunk, és a tapasztalati szakértőnek nincs már több javaslata, akkor készült el a szöveg. Kezdődhet a nyomtatás, vagy az online felületen elhelyezhetjük a könnyen érthető hírt (Csató, 2002).

\section{JÓ GYAKORLATOK A KÖNNYEN ÉRTHETŐ TÖMEGTÁJÉKOZTATÁSRA}

Ebben a fejezetben azokat a külföldi hírportálokat mutatom be, amelyeket nap mint nap olvashatnak könnyen érthető hírekre igényt tartó emberek. Remélem, hogy ezekkel inspirálóan hathatok más hírportálok szerkesztőségeire, és így egyre több hírportál válhat akadálymentessé az értelmi sérült személyek számára.

Nagyon hasznos és tanulságos látni, hogy a világ különböző pontjain milyen területeken, milyen módszerekkel alkalmazzák a mindennapi élet megkönnyítésére a könnyen érthető kommunikációt. Érdekes, hogy a könnyen érthető hírek továbbításával külön szervezetek és vállalatok foglalkoznak, amihez bizony csapatmunkára van szükség.

Több ötletet is meríthettem ezekböl. Motiváltabb lettem azzal, hogy láthattam, hogy az információk akadálymentesítésének nincsenek határai. Az ember akaratától és kreativitásától függ minden. A könnyen érthető hírek hidat képezhetnek köztünk és az információ között. 


\section{JÓ GYAKORLAT AZ USA-BAN}

Az Egyesült Államokban például a The Times indított egyszerüen érthető magazint „The Times in Plain Language” elnevezéssel. Ezek a szövegek nem könnyen érthetők, hanem egyszerüen érthetők: itt nem a könnyen érthető kommunikáció tartalmi és formai szabályait követik. Például nem írnak minden mondatot külön sorba, a tartalom sem feltétlenül rövid. Ugyanakkor egyszerü szavakat használnak, ami az egyszerű megértést biztosítja. A szövegek másodlagosak, vagyis az eredeti Times Magazin cikkeit fordítják le egyszerüen érthető nyelvi szintre. A szövegek mellé mindig egyértelmű, a téma értelmezését segítő képet tesznek a szerkesztők. Jól olvasható betűtípust alkalmaznak, kivéve a címeknél. Ezeknél betűtalpas típust használnak, azonban sokkal nagyobb méretben. A méret hozzájárulhat ahhoz, hogy az olvasó el tudja olvasni a címet, és egyben felkeltse az érdeklődést.

A szövegek után vagy a szövegközben olyan elérhetőségeket vagy online linkeket találunk, amelyekre rákattintva az olvasó további egyszerűen érthető információt olvashat a témáról. Nagyon pozitív tapasztalat, hogy az oldalon különböző nyelvek kiválasztására is lehetőség van. Ha magyarul szeretném olvasni a híreket, akkor a magyar nyelvet kell kiválasztanom. Még afrikai nyelvek választására is van lehetöségünk, ezért igen terjedelmes a nyelvválasztás lehetősége. A fordítás automatikusan generálódik, így nem mindig pontos, de úgy gondolom, ez ezzel együtt is nagyon jó kezdeményezés.

Az érdeklődők olvashatnak politikáról, kultúráról, egészségügyről, oktatásról, bevándorlásról, és még sok más aktuális és a világot érintő témáról. Ezzel hozzájárulnak ahhoz, hogy az alacsony nyelvi kompetenciával rendelkező személyek is napi rendszerességgel tájékozódhassanak a világban zajló eseményekröl.

Számomra újdonság volt, és nagyszerü kezdeményezésnek tartom, hogy a tartalmakat a tanárok is tudják hasznosítani az oktató munka során. Az aktuális hírekhez, információkhoz rövid kérdések, mondhatni tudásfelmérők kapcsolódnak. Ezt a tartalmat a „Tippek a tanároknak” menüpontban érhetjük el.

Az oldalon megtalálható minden elérhetőség (e-mail, telefonszám, Facebook, Twitter), amely segítségével kapcsolatba tudnak kerülni az olvasók a magazin szerkesztőivel, valamint kérdéseket tudnak feltenni, továbbá hozzászólásokat, véleményeket tehetnek közzé.

\section{Jó GYAKORLATOK NÉMETORSZÁGBAN}

A német nyelvü online hírközlő felületeken is fantasztikus példákat találhatunk.

Bár nem többségi hírportál, mégis fontosnak tartom bemutatni a Netzwerk Leichte Sprache oldalát. A honlapról számos könnyen érthető kiadványt tölthetünk le. Amikor 2019-ben először felkerestem a weboldalt, valóban kitünő kiadványokat találtam. Lenyügözött a weboldal külalakja, tartalma és az olvasóknak kínált sokszínű lehetőség. Nagy örömömre így van ez most is, 2021-ben. A honlapon elérhető kiadványokban a könnyen érthető kommunikáció fogalmáról, céljáról, az emberek jogairól, különböző szabályokról olvashatunk. Olyan a felhasználók számára ritkán részletezett témákról is tesznek közzé anyagokat, mint a párkapcsolat, a szexuális együttlét, a fogamzásgátlás, tanácsok a várandós nők számára a terhességi idő alatt vagy magáról a szülésről, illetve a nemi hovatartozás kérdéseiről, mint például a leszbikusság. Ezek 
nagyon komoly témák, amelyeket jól és részletesen magyaráznak meg, úgy, hogy az valóban nagyon sok célcsoport számára érthető. A kiadványokon az Inclusion Europe által bevezetett logót használják. Ez azt jelzi, hogy a kiadványok készítésében és ellenőrzésében tapasztalati szakértő is részt vett.

A weboldal a formai követelmények teljesítése tekintetében is példaértékű. A szövegek mellett mindig egyértelmü, látványos kép található. A betűk megfelelő méretűek. A háttér színe is változtatható: lehet fehér és fekete háttérrel is olvasni. Az olvasó választhatja a felolvasó szoftver opciót is. Így az olvasni nem tudó személyek is hallás útján jutnak hozzá az információkhoz.

A tájékoztatást szolgáló különböző internetes címek, telefonszámok mellett olyan szervezetek adatait is elérjük, amelyek további információt szolgáltatnak az olvasónak, vagy amelyeket felkeresve további tanácsokhoz és hírekhez juthatunk.

Ez a weboldal biztosította számomra a legtanulságosabb és legjobb példákat arra, hogy a 21. században hogyan lehet figyelembe venni minél több emberi igényt, és hogyan lehet professzionálisan alkalmazni a könnyen érthető kommunikációt.

Rendkívül fontosnak tartottam bemutatni az oldalt, mert úgy vélem, olyan innovációról beszélhettünk, amelyek átolvasása ötleteket adhat annak, aki a könnyen érthető kommunikációval szeretne foglalkozni, és azoknak is, akik már ismernek és müködtetnek könnyen érthető weboldalakat, de új innovációkra bukkanhatnak ebben a leírásban.

Egy másik német online felület, a Lebenshilfe weboldal. Örömmel tájékozódtam ezen a honlapon, mert a szövegek mellett olyan képeket használnak, amelyek alapján egyértelművé vált számomra, hogy miről van szó a cikkekben. A weboldal nagyon korszerü és igényes. Olyan témákról lehet olvasni, amelyek minden embernek fontosak, és amelyek hozzájárulhatnak a könnyebb életvitelhez és életvezetéshez. Ilyen téma például a család és a családalapítás, a munka és a munkavállalás, a pénz használata, a nők, az idősek vagy a gyerekek élete, velük kapcsolatos információk.

\section{Jó GYAKORLATOK SVÉDORSZÁGBAN}

Megnéztem a svédországi 8sidor hírportált is. Ez egy valódi könnyen érthető hírportál. Munkám szempontjából ez a hírportál volt a legfontosabb és a legérdekesebb, hiszen hasonló célú és tartalmú információkat igyekszem közölni a Vajdaságban.

A 8 SIDOR oldalán napi rendszerességgel jelennek meg könnyen érthető hírek. Sok a jól értelmezhető kép, melyek nagysága, minősége, tartalma teljes mértékben megfelel a követelményeknek. A képeknek felhívó ereje van, és könnyen értelmezhetők. A felolvasó szoftver lehetőségével is élni tud az olvasó; segítségével egy női vagy férfihang hangosan felolvassa a szöveget, miközben szóról szóra haladva kijelölődnek az abban a pillanatban olvasott szavak. Kiválaszthatjuk, hogy a kijelölt olvasott szó milyen színű és hátterü legyen, milyen legyen a felolvasás hangereje. Lehet választani a lassú, normál vagy gyors felolvasási tempók közül. Ezek a lehetőségek elkápráztatók. Azt láttam, hogy egyszerre számos olvasási igényt ki lehet elégíteni, legyen szó akár látássérült emberről, értelmi sérült emberről, vagy olyan személyről, aki nem tud olvasni, de a hírekhez így egyenlő eséllyel tud ő is hozzájutni. A weboldalon számos rovatot múködtetnek: kultúra, sport, politika, gasztronómia vagy aktuális időjárás-jelentések. 
Ez a weboldal azt bizonyította számomra, hogy nincsen lehetetlen a könnyen érthető kommunikációban, és a határokat mindig tágítani lehet. Egy kis kreativitással és ambícióval a médiát minden ember számára elérhetővé, olvashatóvá lehet tenni.

\section{Jó GYAKORLATOK BELGIUMBÓL}

A Belgiumban működő Inclusion Europe weboldala is remek példa a könnyen érthető kommunikáció alkalmazására. A honlap valójában kétnyelvü: a sztenderd nyelv mellett a könnyen érthető kommunikáció európai logójára klikkelve jutunk el a könynyen érthető nyelvi változathoz. A szervezet föleg önérvényesítéssel foglalkozik, így a szavazati jogokról, döntéshozatalról, ezekhez kapcsolódó témákról jelentet meg cikkeket angol nyelven.

A weboldal nagyon fiatalosan, lendületesen felépített. Böven találunk videókat és jól értelmezhető képeket is. Minden szükséges információ, elérhetőség és együttmüködő szervezet neve és elnöke is megtalálható a kapcsolódó tartalmaknál (így a magyarországi ÉFOÉSZ is). A szervezet megtalálható más közösségi oldalakon is (a Facebookon, a Twitteren, van saját csatornája a YouTube-on is).

Az Inclusion Europe tartalmas leírást adott ki 2020 márciusában arról, hogy a koronavírus-járvány milyen hatással volt és van az értelmi sérült emberek életére. Több tagország is csatlakozott a kezdeményezéshez. Ezért összesen 7 nyelven jelent meg a kiadvány (angol, francia, német, spanyol, román, magyar, olasz).

Az Inclusion Europe önérvényesítéssel foglalkozó önálló szervezete az EPSA (European Platform of Self-Advocacy; Önérvényesítők Európai Platformja). Az EPSA könnyen érthető hírlevele az „Európa Nekünk”. A hírlevél külalakjára, átláthatóságára és értelmezhetőségére is nagyon ügyelnek a szerkesztők. A hírlevélben olvashatunk például arról, hogy az Európai Parlament milyen fontos döntéseket hozott a fogyatékos emberek jogaival kapcsolatban, vagy arról, hogy a karantén milyen negatívumokkal vagy pozitívumokkal járt az értelmi sérült emberek számára. Olvashatunk az értelmi sérült emberek oktatási jogairól. Konkrét tapasztalatokat is megosztanak arról, hogy milyen harcokat kellett megvívni, hogy érvényesíteni tudják az oktatáshoz való jogukat. Érdekes írás található a befogadó iskolákról és a befogadó társadalomról. Videókat tekinthetünk meg, amelyek a fogyatékos emberek munkavállalását támogatják. A hírlevelek végén tartalmas szómagyarázat segíti az olvasót. A szómagyarázatban megtalálható az összes olyan kifejezés, amely a hírlevélben megtalálható, és amelyek az értelmi sérült emberek számára vélhetően nehezebben értelmezhetők, vagy éppen idegen kifejezések. Ilyen szavak például a diszkrimináció, az Európai Parlament, a gondnokság, a hozzáférhetőség, az inkluzív oktatás és munka.

\section{Jó GYAKORLATOK MAGYARORSZÁGRÓL}

Magyarországon egyelöre talán kevesebb a lehetőség könnyen érthető üzeneteket olvasására. Ilyen honlap - bár nem hírportál - az ÉFOÉSZ vagy a Down Alapítvány honlapja.

Az ÉFOÉSZ önérvényesítőinek weboldala az Együtt Velünk - Önérvényesítés azonban egyfajta szakmai hírportálként müködik. Az oldalon megtaláljuk az Európai Unió és az Európai Bizottság bemutatását, híreket a szavazati jogról, mint például 
a „Visszakapják a választójogukat a gondnokság alatt álló emberek Németországban!" című cikk. A pénzkezelés témájával is foglalkoznak, amely részletesen bemutatja a bankszámla nyitásának folyamatát, és azt, hogy hogyan kell pénzt felvenni az automatákból.

A tartalmi és formai követelményeknek is megfelelnek a könnyen érthető cikkek. A betük és a címek megfelelö méretűek. A címek után többnyire nagyméretüek a képek, amelyek jól láthatóak, jó minőségűek, és mindig a kulcstémára utalnak. A kulcsszavakat félkövér betütípussal emelik ki. Találunk hivatkozásokat, linkeket, kiadványokat is.

A Down Alapítvány weboldalán a KÉR menüpontban találhatunk több könnyen érthető kiadványt. Olvashatunk illemtani szokásokról, ügyintézésekröl, az emberek jogairól, egészséges életmódról, közlekedési szabályokról, turizmusról. A mostanában az egyik igen aktuális témáról, a COVID-19-ről is fontos tudnivalókat lehet megtalálni.

Farkasné Gönczi Rita honlapja jól szolgálja a könnyen érthető kommunikáció hazai terjesztését. Olvashatunk könnyen érthető receptekről vagy főzési, sütési eljárásokról, a konyhai gépek használatáról, de komolyabb témákat érintő kiadványok is jelen vannak az oldalon. Ilyen a „Fogyatékosság és bántalmazás” című könnyen érthető kiadvány (Borbás B. és mtsai, 2017), a választójogokról szóló kiadvány, vagy a fogyatékosságügyi ENSZ egyezmény. Ezen a weboldalon is olvashatunk a koronavírusról, illetve arról, hogy milyen új szabályokat vezettek be Magyarországon a koronavírus-járvány következtében.

A kiadványok megfelelő betűméretben és betűformázással íródtak, minden könynyen érthető üzenetben megfelelő nagyságú, minőségű és tartalmú kép, illusztráció vagy szimbólum segíti az értelmezést. A „Fogyatékosság és bántalmazás” című kiadványban például lehetősége van az olvasónak kiválasztani 4 könnyen érthető forma közül azt a szintet, amely a legjobban megfelel számára. A négy különböző szintet négy különböző színnel jelölik. Az első, kékkel jelölt szint a hosszú szövegeket jelöli, amely kevesebb képet tartalmaz. A második, pirossal jelölt szint rövid szövegeket tartalmaz, és néhány képpel támogatja a megértést. $A$ harmadik, sárgával jelzett szinten felsorolásokat, listákat lehet olvasni arról, hogy mit kell tenni bántalmazáskor, valamint képeket is használnak. A negyedik, zölddel jelölt szint képsorozatokat tartalmaz a bántalmazás fajtáiról, és arról, hogy hova és kihez lehet fordulni bántalmazás esetén, mit kell tenni, ha bántalmazás történt. A kiadvány végén adatbázist találunk azokról az intézményekről (logóval és elérhetőséggel) amelyek segíteni tudnak bántalmazás esetén.

\section{KÖNNYEN ÉRTHETŐ KOMMUNIKÁCIÓ SZERBIÁBAN}

Tapasztalataim szerint Szerbiában még kevés ember hallott a könnyen érthető kommunikációról. Az ország gyógypedagógiai képzést folytató egyetemein még nem oktatják, nem ismertetik a hallgatókkal ezt a módszert. Nem tudok egyetlen szerb nyelvű könnyen érthető kiadványról vagy szakirodalomról sem. A Vajdaságban a Szegedi Tudományegyetem Juhász Gyula Pedagógusképző Kar Gyógypedagógus-képző Intézete 2018-ban indított először kétéves gyógypedagógiai témájú szak- 
irányú továbbképzést, aminek köszönhetően egyre több vajdasági magyar, illetve szerb anyanyelvű kollégához jut el a könnyen érthetö kommunikáció.

Még mindig igaz, hogy a Vajdaságban inkább magyar nyelven elterjedtebb a könynyen érthető kommunikáció, föként a fiatalság körében. Ennek az is az oka, hogy a magyar ajkú vajdasági fiatal gyógypedagógusok, akik Magyarországon fejezték be egyetemi tanulmányaikat, visszatérésükkor mesélnek a megszerzett ismeretekröl, ideértve a könnyen érthető kommunikációról szerzett tudásukat és gyakorlatukat is.

\section{KÖNNYEN ÉRTHETŐ HÍRPORTÁL LÉTREHOZÁSA A VAJDASÁGBAN}

Munkám során célként tüztem ki azt, hogy a könnyen érthető kommunikáció fogalma ne csak a vajdasági magyar nyelvü gyógypedagógusok és értelmiségiek körében tudatosuljon, hanem a hétköznapi vajdasági ember is találkozhasson vele. Így az emberek egy része talán már nem lepődik meg egy-egy KÉK-hír láttán, és nem háborodnak fel azon, hogy minek kell ilyen „ovis” szinten megírni egy hírt (saját tapasztalat, a KÉK-hírekhez írt kommentek alapján használom ezt a kifejezést).

De kezdjük az elejéröl. Amikor 2019-ben meg kellett írnom a szakirányú továbbképzés végén a szakdolgozatomat, úgy döntöttem, hogy a könnyen érthető kommunikáció lesz a témám. Tudtam, hogy Magyarországon már kiváló minták léteznek. Elhatároztam, hogy megismertetem a vajdasági emberekkel is azt, hogy mit jelent a könnyen érthető kommunikáció, és miért olyan fontos. Az akkori témavezető tanárommal, dr. Horváth Péter Lászlóval megbeszéltem, hogy meglátogatom a szabadkai Pannon RTV-t, azért hogy beszélgetni tudjak a föszerkesztőjével. A cél az volt, hogy megszerezzem a támogatását könnyen érthető másodlagos hírek közzétételéhez az online hírportál oldalán. A szerkesztőség, később az igazgatóság is nagyon pozitívan és nyitottan állt az ötlethez, ezért igent mondtak a projektre. 2019. január 24-én megkezdődött az együttműködés a PannonRTV-vel.

Egy héten többször ellátogattam a médiaházba, annak érdekében, hogy akár több riporterrel és szerkesztővel együtt írhassak könnyen érthető híreket. Fontosnak tartottam, hogy minél több médiában dolgozó ember ismerje meg a könnyen érthető kommunikáció fogalmát, fontosságát és módszertanát. Meséltem nekik egy-két külföldi jó gyakorlatról. Elmagyaráztam a formai és tartalmi szabályokat, mutattam könynyen érthető tartalmakat és példákat. A hírek kiválasztása és megfogalmazása előtt minden munkatársnak elmagyaráztam, hogy miről van szó, és mire számíthatnak a munka során. Folyamatosan készítettem a KÉK-híreket. Az elkészült hírek között volt politika, kultúra, sport, oktatás, egészségügy és még sorolhatnám. A Pannon RTV épületébe öt héten keresztül jártam be, amely időszak alatt több riporterrel is volt szerencsém közös munkában részt venni. Láthattam, hallhattam, tapasztalhattam több különböző véleményt a könnyen érthető kommunikációval kapcsolatban. Voltak, akik lelkesen dolgoztak, azonnal átérezték a könnyen érthető hírek létjogosultságát, de voltak olyan újságírók is, akik láthatóan nem szerették volna ezen az új területen kipróbálni magukat. Ilyenkor fontosnak tartottam a közös beszélgetést. Arra jöttem rá, hogy nagyon sok embernek téves információja van az értelmi sérült emberekröl, ezért negatív attitűd alakult ki bennük. Abban azonban mindenki egyetértett, hogy az információkhoz, a tájékozódáshoz minden embernek joga van, és nekünk, akik a híreket alkotjuk, kell erre megteremteni a lehetőségeket. 
Külön örömöt okozott, hogy a Pannon RTV vezetősége komoly igényt látott a hírek kiadására, és így a szakdolgozat megvédését követően felkért a KÉK-hírek írásának folytatására. Így ma már otthonról, önállóan végzem a szövegek írását. Napi 2-4 anyag kerül ki a weboldalra, ahol külön rovatot kaptak a könnyen érhető hírek.

Az elmúlt két évben sok pozitív élményben volt részem a könnyen érhető hírek írása alatt, illetve nagyon sok pozitív visszajelzés is érkezett a Pannon RTV-be és személyem irányába is. Természetesen a mai napig vannak olyan emberek, akik nem értik, hogy mi is a könnyen érthető kommunikáció lényege, és ezt szóvá is teszik akár a könnyen érhető hírek alatt. Sokszor gúnyos hozzászólásokat írnak a facebook. com/pannonrtv oldalán is. Mégis úgy gondolom, hogy a negatív kritikák közül az inkább építő jellegüek segítik a további innovációk létrejöttét. Ennek kapcsán kezdtem el gondolkodni annak megelőzésén, hogy tájékozatlan emberek minden egyes hír alatt elkezdjék kritizálni nem is magát a hír tartalmát, hanem egyszerűen a KÉK-hírek megnevezést (sokan a KÉK szót ugyanis a bünügyi hírekkel azonosították).

Ekkor született meg az ötlet, hogy minden könnyen érthető hír alá két kulcsmondatot helyezzünk el link formájában arról, hogy mit jelent a KÉK, illetve, hogy kik tartoznak az elsődleges célcsoportba. Ha erre a linkre rákattint az olvasó, akkor a KÉK-hírek rovatában találja magát, ahol már részletes leírást olvashat a könnyen érhető kommunikációról. Talán ennek a fejlesztésnek a hatásaként ma már sokkal kevesebb ember támadja a KÉK-híreket, és csak elvétve találunk pejoratív kommenteket a hírek alatt.

Egy másik nagyszerü fejlesztés és élmény volt számomra, amikor 2019-ben egy magyarországi pályázaton vehettem részt, melynek keretében egy rövidfilmet kellett készíteni. Témájaként természetesen a KÉK-et, a KÉK-híreket, valamint a Pannon RTV-vel való közös innovációt választottam. Ezzel az innovációval elnyertem a közönségdíjat. A pályázaton való részvétel és a film egri bemutatása azért is volt számomra nagyon fontos és meghatározó, mert az egész Kárpát-medencéből érkeztek magyar ajkú fiatalok és felnőttek. A zsüriben olyan jelentős eredményeket elért újságírók voltak, akik tanácsaikkal és észrevételeikkel hozzájárultak szakmai fejlődésemhez. Megerősítettek abban, hogy a KÉK-hírekre szükség van, nemcsak a Vajdaságban, hanem minden olyan területen, ahol értelmi sérült emberek élnek. A kisfilmem felkerült a Pannon RTV weboldalára is. Az sem volt kérdés számomra, hogy a filmről és a pályázati részvételről megírjam a KÉK-hírt, aminek szintén nagy olvasottsága volt, és igen nagy örömömre sokan osztották meg a közösségi felületeken is.

Nagy örömömre szolgál, hogy a 2 év alatt több alkalommal is elöfordult, hogy egy-egy könnyen érthető hír volt a weboldal legolvasottabb híre. Ilyen volt például, amikor 2020 májusában egy KÉK-hír bekerült az év első 10 legolvasottabb hírei közé, (106168 ember olvasta el pár nap alatt a koronavírus idején az oktatással foglalkozó hírt). Amikor most, 2021. február elején írom ezt a tanulmányt, az egyik könnyen érthető cikk az első a legnépszerübb cikkek listáján.

Ezek a visszacsatolások, és a sok értelmi sérült gyermek, fiatal és szüleik pozitív visszajelzése adja az erőt a munkához. Vinni kell a hírét minél messzebbre, hogy akár a határokon kívül, például Szerbiában élő magyarok is tudjanak róla, hogy a média lehet mindenkié, és nem szabad falakat építeni egyetlen ember és a tömegtájékoztatás elé sem. 
2020 éppen a koronavírus-járvány miatt sok új kihívást állított elénk, ami egyben még több könnyen érthető hír megírásának lehetőségét eredményezte. Fontosnak tartottam, hogy minden új szabályról, minden új óvintézkedésröl, illetve magáról a koronavírus fogalmáról tájékoztatást adjak az értelmi sérült embereknek.

Szerbiában több mint fél évig távoktatás zajlott, és sok interjút hallhattunk, láthattunk arról, hogy a többségi iskolákban hogyan élték meg ezt az új tanítási módszert a gyerekek, a szülök, illetve a tanárok. Ennek mintájára kerestem fel a Pannon RTV szerkesztőjét, hogy mi lenne, ha Szabadkán is készítenénk egy rövid interjút arról, hogy a fogyatékos gyermekek és tanáraik hogyan tudtak alkalmazkodni a távoktatás kihivásaihoz, és hogy ők hogyan élték meg például a kijárási tilalmakat. Ahogy már említettem, a Pannon RTV szerkesztőségének csapata igen nyitott és pozitív emberekből áll, ezért rögtön igent mondtak az ötletemre. Arra azonban nem számítottam, hogy azt fogják kérni, hogy én magam állítsam össze, készítsem el, és írjam meg az interjúkat. Nagy büszkeséggel tölt el, hogy sikeresen elkészült két interjú, ami szintén felkerült a Pannon RTV weboldalára. Erről a munkáról az eredeti hírt és az elsődleges könnyen érhető hírt is én készíthettem el.

2020 novemberében egy újabb együttmüködésre nyílt lehetőség. Egy Magyarországon élő olyan személy keresett meg, aki szintén sokat foglalkozik a könnyen érthető kommunikációval, emellett önérvényesítő is. Látta a könnyen érhető kisfilmem. Ezért felkeresett azzal a kéréssel, hogy írjak egy könnyen érhető hírt a Magyar Speciális Független Filmszemle programjáról, és legyen ez a vajdasági emberek számára is nyilvános. Így jutott el ennek a fontos kezdeményezésnek a híre (és talán a lehetősége is) a vajdasági emberekhez.

\section{ÖSSZEFOGLALÁS}

Ezek az emlékek és eredmények nagy motivációt adnak a munkám további folytatásához. Még nagyobb öröm, hogy számomra ez nem is jelent munkát, hanem szeretett hobbimként élem meg. Ehhez a szabadságérzethez a Pannon RTV rugalmassága és bizalma is hozzájárul: valóban akkor, annyit és azt a tartalmú KÉK-hírt írhatom meg napi szintem, ami nekem jólesik. Az elmúlt két évben több mint 1500 KÉK-hír megírásával és megosztásával tudtam egy élhetőbb és érthetőbb világ megteremtéséhez hozzájárulni.

\section{Irodalom}

a Fogyatékossággal élő személyek jogairól szóló ENSZ egyezmény, 2006

Borbás B., Farkasné Gönczi R. \& Rajnai E. (2017). Fogyatékosság és bántalmazás. FSZK, Budapest.

Csató Zs. (szerk.) (2002). Egyszerủen, érthetően: útmutató könnyen érthető tájékoztatók készítéséhez. ÉFOÉSZ, Budapest.

Farkasné Gönczi R. (2017). Fogalom. http://konnyenertheto.gonczirita.hu/ismeret/fogalom/ Letöltés ideje: 2021.02.08.

Farkasné Gönczi R. \& Graf-Jaksa É. (2009). Könnyen érthető kommunikáció. In Pandula A., Szatmári P., Vincze T., Farkasné Gönczi R. \& Graf-Jaksa É. (szerk.), Kommunikációs és információs technológiák és fogyatékosságügy. ELTE Bárczi Gusztáv Gyógypedagógiai Kar, Budapest. 80-100.

Inclusion Europe \& ÉFOÉSZ (2009). Információt mindenkinek! A könnyen érthető kommunikáció európai alapelvei. Inclusion Europe - ÉFOÉSZ, Brüsszel - Budapest. 
Példa a KÉK hírre:

Ma van Szent Száva ünnepnapja Szerbiában.

Ma január 27-e, szerda van.

Szent Száva a szerb oktatás

és a szerb kultúra védőszentje.

Az oktatás tanítást jelent.

Sok szerb ember ortodox vallású.

Az ortodox is a keresztény valláshoz tartozik.

Szent Száva volt az önálló szerb ortodox egyház megalapítója.

Szent Száva volt az 1. szerb érsek.

Az érsek szó egyházi főpapot, vagyis püspököt jelent.

Szent Száva író, fordító

és iskolaalapító is volt.

Január 27-e, vagyis Szent Száva napja

1840-ben lett iskolai ünnepnap Szerbiában.

Az 1840-es év 181 évvel ezelőtt volt.

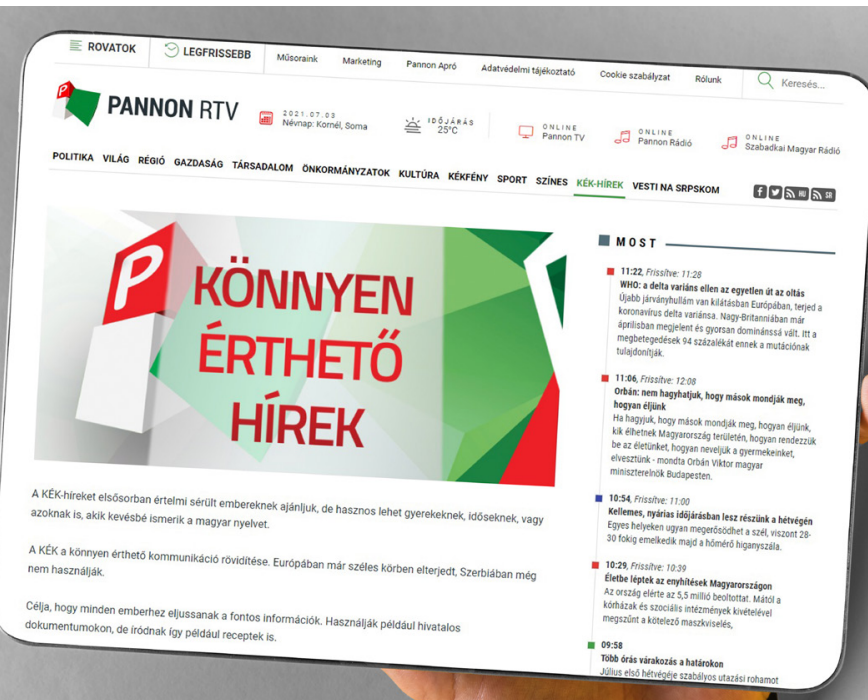

